Jurnal Bimbingan Konseling
$10(1)(2021): 8-13$
UNNES

\title{
The Relationship between Creative Thinking, Problem Solving Skills, and Self Efficacy with Work Readiness
}

\author{
Alis Nihlatin Nisa ${ }^{凶}$, Dwi Yuwono Puji Sugiharto, Awalya Awalya \\ ${ }^{1 .}$ SMK Negeri 2 Semarang, Indonesia \\ 2. Universitas Negeri Semarang, Indonesia
}

\begin{abstract}
Student's work readiness is related to individual abilities such as creative thinking, problem solving skills, and self-efficacy. However, the readiness is sometimes not matched by the expected requirements from industrial world. Hence, this study strived to analyze the relationship between creative thinking, problem solving skills, and self-efficacy with the work readiness of Public Vocational High School students in Semarang City. Regarding sample, this study involved 372 students in 6 Public Vocational High School in Semarang City chosen using Cluster Random Sampling. The sample data were collected through the instruments of creative thinking scale, Problem Solving Inventory (PSI), General Self-Efficacy (GSE), and work readiness scale. The findings showed that; creative thinking, problem solving skills and self-efficacy had positive relationships with work readiness. In details, self-efficacy variable owned the strongest relationship among other variables. Thus, the higher the creative thinking, problem solving skills, and self-efficacy students have, the higher work readiness in facing the industrial world and the world of work would be.
\end{abstract}




\section{INTRODUCTION}

Work readiness focuses on individual personal traits such as work attitudes and the body defense mechanism required in getting and perpetuating jobs (Brady, 2010). In addition, Pool and Sewell (2007) argue that high work readiness needs several things, namely expertise, personality, intelligence and broad insight, and understanding. All these qualifications will enable someone to choose and feel comfortable with his jobs so that at the end he can achieve success.

Statistics Indonesia or BPS summed up the level of open unemployment rate based on the highest educational level someone graduates from the August 2018 - August 2020 and concludes that Vocational High School graduates are still on the top position compared to other levels in the last three years, namely $11.18 \%, 10.36 \%$, and $13.55 \%$. This fact proves that Vocational High School has not yet met its vision, namely to create graduates who are ready to work (Yudantoko and Arifin, 2016)

Alimudin, Permana, and Tatang (2018) in their study claim most of Vocational High School students are ready to work in the automotive body repair industry. In the same way, a study by Tanius (2015) concludes that most of the respondents state ready to enter the labor market, realize the required skills, and made preparations to improve. However, those study found some respondents are not sure about the work.

Facts on the ground show that most entrepreneurs complain about the graduates' work readiness for long-term demand (CasnerLotto and Barrington, 2006). Some factors surely contribute to this issue either from within or outside (Sofyan, et al, 2018). The high demands of the world of work and skills to master by students can be a big obstacle for work readiness.

Hulu (2020) found learning creativity has a positive and significant relationship with job readiness. However, the creativity variable was found to have lower score than soft-skill variable. Even though it has low contribution, creative thinking positively contributes to work readiness.

A study by Crawford dan Dalton (2011). recognizes that one thing that often becomes a problem or obstacle in workplace is problem solving skills (40.85). Alternatively, the findings of Brungardt's study (2011) revealed students have low soft skills in problem solving and adaptability (33.3\%). Of these two studies, problem solving skills are positively related to individual work readiness.

Utami's study (2013) discovered selfefficacy has a positive contribution to student's work readiness. The higher self-efficacy a student has, the work readiness he would have.

By referring to the above description, this study focused on analyzing the relationship between creative thinking, problem solving skills, and self-efficacy with Vocational High School students' work readiness. Findings of this study would contribute some implications for guidance and counseling teacher at Vocational High School in improving students' ability, including creative thinking, problem solving skills, and self-efficacy so that student's work readiness improves and can minimize the unemployment rate of Vocational High School graduates.

\section{METHODS}

This correlational study involved six Public Vocational High School in Semarang City with the subjects of the third-year students in class XII and XIII amounted to 5,276 students. To sample the students, the researchers employed Cluster Random Sampling technique, while the total sample was calculated using Slovin formula with an error rate of $5 \%$. Through this formula, 372 students consisting of 221 female students and 151 male students were selected.

Students' creative thinking data were obtained using creative thinking scale. It was developed by referring to Munandar's concepts (2009) consisting of four indicators, namely fluency, flexibility, authenticity, and decipherment. Upon the development, the 
researchers got 22 items with a Likert scale for answers ranging from 1 (very appropriate) to 4 (very inappropriate) and valid $(\mathrm{Rxy}=0.356-$ 0.633) with the Cronbach Alpha criteria of 0.828 .

General Self-Efficacy (GSE) scale by Ralf Schwazer \& Matthias Jerusalem (1995) was adopted thorough several stages, namely translating the instrument with help of language expert and back-translating it to be relevant to Indonesian condition so that the items in the instrument are easy to understand and approved by expert validators. This instrument has 10 items to measure level, strength, and generality. Its answer ranges from 1 (very appropriate) to 4 (very inappropriate) with valid $(\mathrm{Rxy}=0.391$ -
0.789) valid and Cronbach Alpha criteria of 0.815. In this study, the data collected form the instruments were analyzed using multiple linear regression analysis technique.

\section{RESULTS AND DISCUSSION}

According to descriptive statistics, the mean, and standard deviation of each variable was $($ Mean $=112.10 ; \mathrm{SD}=12.72$ ) for work readiness, $($ Mean $=62.77 ; \mathrm{SD}=8.06)$ for creative thinking, $($ Mean $=104.54 ; \mathrm{SD}=11.28)$ for problem solving skills, and (Mean $=30.08$; $\mathrm{SD}=4.27)$ for self-efficacy. The complete description is presented in Table 1.

Table 1. Descriptive Statistics

\begin{tabular}{llll}
\hline Variables & $\mathrm{N}$ & Mean & SD \\
\hline Work Readiness & 372 & 112.10 & 12.72 \\
Creative Thinking & 372 & 62.77 & 8.06 \\
Problem Solving Skills & 372 & 104.54 & 11.28 \\
Self-Efficacy & 372 & 30.08 & 4.27 \\
\hline
\end{tabular}

The results of regression test showed creative thinking, problem solving skills and selfefficacy had relationships with work readiness proved by the value of $(\mathrm{R}=0.47, \mathrm{~F}=40.14, \mathrm{p}$ $<0.01$ ). Both creative thinking, problem solving skills, and self-efficacy explained the variants of job readiness by $22 \%(\mathrm{R} 2=0.22)$. As presented in table 2, positive creative thinking had a relationship with job readiness $(\beta=0.161 ; \mathrm{p}$ $<0.05$ ). The same went for problem solving skills which were positively related to job readiness ( $\beta$ $=0.221 ; \mathrm{p}<0.01)$. Similarly, self-efficacy had a relationship with job readiness $(\beta=0.323 ; \mathrm{p}$ $<0.01)$.

Table 2. The Results of Multiple Linear Regression of Work Readiness

\begin{tabular}{llll}
\hline Predictors & $\beta$ & $\mathrm{t}$ & $\mathrm{p}$ \\
\hline Creative Thinking & 0.161 & 2.17 & $<0.05$ \\
Problem Solving Skills & 0.221 & 3.80 & $<0.01$ \\
Self-Efficacy & 0.323 & 2.11 & $<0.01$ \\
\hline
\end{tabular}

On the report of the findings, the three predictors in this study, namely creative thinking, problem solving skills, and self-efficacy were jointly correlated with work readiness. When further correlated, each predictor had a positive correlation with work readiness.

Some previous studies gain the same results as the current study findings such as studies by Hulu (2020) and Aprianti (2015). In her study, Aprianti (2015) found a significant relationship between creativity and work readiness evidenced by the results of partial data analysis by $21.8 \%$. It signifies the higher creativity or creative thinking, the higher student's work readiness will be.

Creative thinking is an ability to think about new ideas production, new ways, new solutions, new methods, and new procedures 
(Redhana, 2014). Munandar (2009) further considers creativity or creative thinking as an ability to see various possibilities of solutions for the increasingly complex problems in which individuals are expected to think and form new ways or change the old ways creatively to survive in more tougher competitions. Even more, individuals with creative thinking abilities and disposition tend to produce more ideas to solve general administrative problems better and thoroughly.

Other studies in line with the findings are from Crawford dan Dalton (2011) and Brungardt (2011), namely problem solving skills contribute to work readiness. The higher problem solving skills owned by individuals, the higher work readiness they would have. Rojuli (2017) gives his views in the way problem solving skills take part in one's work readiness, namely the higher problem skills would contribute to the higher work readiness too and vice versa.

Heppner and Petersen (1982). divide two tendencies in individual's nature when encountering a problem, including approaching or avoiding the problem (approach-avoidance style). Moreover, findings by Ulya (2016) conclude good problem solving skills will enable individuals to identify problems and define the goals of problem solving. For those who are about to enter the world of work, having these skills will prepare them to face any challenges and find the solutions.

Stein and Book (2002) consider that individuals with good problem solving skills are supposed to be able to understand problems, formulate problems as clear as possible, find many possible solutions, make decisions of alternative solutions, assess the implementation of solutions, and repeat the solving process if the problems are not yet solved.

In this study, self-efficacy was found having a positive relationship with work readiness. Consistently, it is related to Utami's study (2013) that self-efficacy has a positive contribution to student's work readiness. However, Kurniawati's study (2016) found different results, namely self-efficacy only gives smaller contribution by $8.58 \%$ to work readiness. Unlike the previous studies, the current study discovered a positive relationship between self-efficacy and work readiness. This is different from what was found by Utami (2013) and Kurniawati (2016) who conclude self-efficacy as a variable which has positive relationship, but not the dominant variable compared to the other. In contrast, this study found self-efficacy had a more positive and stronger relationship compared to problem solving skills and creative thinking. It is similar to what Wibowo and Wagimin (2017) state that improving career selfefficacy and expected goals would help students face risks and problems in choosing career and determine the future goals.

Alexsander, Purwanto, and Awalya (2020) define high self-efficacy tends to enable someone to make choices in career decision making, face challenges, and accept risks from the actions performed. This is supported by Hejazi, Shahraray, Farsinejad, and Asgary (2009) who explains self-efficacy influences students in choosing activities. Those who have low self-efficacy may avoid subjects which have a lot of assignments, especially the challenging ones, while students with high self-efficacy are eager to do the tasks

Some implications for the service of guidance and counseling in Vocational High School regarding the findings of this study include the emphasis on three aspects (Gladding, 2015), namely stimulating career development, providing care, and assisting with work placement. Another implication deals with the provision of career guidance and counseling to reinforce students' work readiness in entering the world of work and industry, covering creative thinking, problem solving skills, and self-efficacy. Hence, students are more prepared in entering industrial world and more ready for various challenges to face.

Apart its contributions, this study was still limited to Vocational High School students and the investigation of creative thinking, problem solving skills, and self-efficacy, while there are 
still a lot of abilities and skills related to work readiness.

\section{CONCLUSION}

Based on the findings, the researchers drew some conclusions. First, creative thinking has a positive relationship with work readiness, problem solving skill has a positive relationship with work readiness, and self-efficacy has a more positive relationship with work readiness.

To follow up the findings, some suggestions are given, namely guidance and counseling teacher of Vocational High School should give more focus on career when giving a service so that student's work readiness can improve. The service can be given in individual or groups settings and concern about creative thinking, problem solving skills, and selfefficacy. Furthermore, it is advisable for further researchers to conduct studies on job readiness with more complex soft skill variables in accordance with the demands of the industrial world in the 21 st century.

\section{REFRENCES}

Alexsander, D., Purwanto, E., \& Awalya, A. (2020). The Use of Career Self-Efficacy in Mediating Career Decision Ambiguity Tolerance and Career Decision-Making Difficulties. Jurnal Bimbingan Konseling, 9(2), 64-69. Do 10.15294/JUBK.V9I2.35932

Alimudin, Imam A, Permana, Tatang, Sriyono. (2018). Studi Kesiapan Kerja Peserta Didik SMK Untuk Bekerja di Industri Perbaikan Bodi Otomotif. Journal of Mechanical Engineering Education, 5(2), 179-185.

Ana, A., Wibowo, M. E., \&Wagimin, W. (2017). Group guidance with role playing techniques to improve students' selfefficacy and career outcome expectations. Journal Guidance and Counseling, 6(1), 49-53.

Aprianti, Dwi Wahyuni Machmud Sugandi. (2015). Kontribusi Soft Skills Terhadap
Kesiapan Kerja Siswa Keahlian Teknik Gambar Bangunan Sekolah Menengah Kejuruan. Jurnal Bangunan, 20(1), 2330.

BPS. (2020). BRS Naker Agustus 2020 Keadaan Ketenagakerjaan Indonesia Agustus Keadaan Ketenagakerjaan Indonesia Agustus Th. XXIII. 1-24.

Brady, R.P. (2010). Work Readiness Inventory: Administrators' Guide. JIST Publishing.

Brungardt, Christie (2011). The intersection between soft skill development and leadership education. Journal of Leadership Education. 10 (1).1-22.

Casner-Lotto, J., \& Barrington, L. (2006). Are they really ready to work? Employers' perspectives on the basic knowledge and applied skills of new entrants to the 21st century US workforce. Partnership for 21st Century Skills. 1 Massachusetts Avenue NW Suite 700, Washington, DC 20001.

Crawford, P., \& Dalton, R. O. B. E. R. T. (2011). Making Our Graduates Competitive in the Workforce: What Soft Skills Do Students, Faculty, Alum and Employers Value. Association of Public and Land-grant Universities, the University-Industry Consortium, Michigan State University and MSU AgBio.

Gladding, S. T. (2012). Konseling profesi yang menyeluruh. Jakarta: Indeks.

Hejazi, E., Shahraray, M., Farsinejad, M., \& Asgary, A. (2009). Identity styles and academic achievement: Mediating role of academic self-efficacy. Social Psychology of Education, 12(1), 123-135.

Heppner, P. P., \& Petersen, C. H. (1982). The development and implications of a personal problem-solving inventory. Journal of counseling psychology, 29(1), 66.

Hulu, F. (2020). Pengaruh Kreativitas Belajar Dan Soft Skill Mahasiswa Terhadap Kesiapan Kerja Mahasiswa Pendidikan Bisnis 2016. NIAGAWAN, 9(3), 263270 . 
Myszkowski, N., Storme, M., Davila, A., \& Lubart, T. (2015). Managerial creative problem solving and the big five personality traits: Distinguishing divergent and convergent abilities. Journal of Management Development, 34(6), 674-684. Doi 10.1108/JMD-122013-0160

Munandar, U. (2009). Kreatifitas pengembangan anak berbakat. Jakarta: Rineka Cipta.

Kurniawati, A., \& Arief, S. (2016). Pengaruh Efikasi Diri, Minat Kerja, Dan Bimbingan Karir Terhadap Kesiapan Kerja Siswa Smk Program Kehlian Akuntansi. Economic Education Analysis Journal. 5(1).

Pool, L. D. dan Sewell, P. (2007). The key to employability: developing a practical model of graduate employability. Journal education and training,49(4), 277-289.

Redhana, I W dan Sya'ban, Suhemi. (2014). Pengembangan Tes Keterampilan Berpikir Kreatif. Seminar Nasional Riset Inovatif II. 18-25.

Rojuli, S, A. Rahayu, and Disman. (2017). Observational Learning on Industry Work Practices toward Job Readiness.," Educ. Res. Rev 12(9).554-558.

Schwarzer, R. \& Jerusalem, M. (1995). Generalized Self-Efficacy scale. In J. Weinman, S. Wright, \& M. Johnston, Measures in health psychology: A user's portfolio. Causal and control beliefs (pp. 35-37). Windsor, UK: NFER-NELSON.

Stein, S. \& Book, H. (2002). Ledakan EQ (15 prinsip dasar kecerdasan emosional meraih sukses). Bandung: Kaifa Offset.

Sofyan, M. A. H., Muladi, \& Sugandi, R. M. (2018). Faktor-Faktor yang Memengaruhi Keterlaksanaan Unit Produksi SMK pada Program Studi Keahlian Teknik Komputer dan Informatika di Kota Malang. Jurnal Pendidikan: Teori, Penelitian, Dan Pengembangan, 3(5), 552-557. doi.org/10.17977/jptpp.v3i5.10980

Tanius, E., \& Susah, S. (2015). Employability skill readiness among business students. Journal International Ilmu Pengetahuan dan Penelitian (IJSR), 4(8), 511-516.

Ulya, Himmatul. (2016). Profil Kemampuan Pemecahan Masalah Siswa Bermotivasi Belajar Tinggi Berdasarkan Ideal Problem Solving. Jurnal Konseling GUSJIGANG 2(1). 90-96.

Utami, Y. G. D., \& Hudaniah. (2013). Self efficacy dengan kesiapan kerja siswa sekolah menengah kejuruan. Jurnal Ilmu Psikologi Terapan, 1(1), 48-49.

Yudantoko, A. dan Arifin, Z. (2016). Profil Kompetensi Dunia Kerja Bidang Perbaikan Bodi Otomotif dan Tingkat Relevansinya dengan Dunia Pendidikan. Jurnal Pendidikan Vokasi, 6(2), 127-1. 